\title{
KREPŠININKŲ, FUTBOLININKŲ IR NESPORTUOJANČIŲJŲ ATSIGAVIMO PROCESO YPATYBĖS PO SUBMAKSIMALAUS FIZINIO KRŪVIO MÉGINIO
}

\author{
Renata Žumbakyte் $\dot{1}^{1,2}$, Alfonsas Vainoras ${ }^{2}$, Alma Kajẻnienè ${ }^{2}$, \\ Kristina Berškiené $\dot{e}^{2,3}$, Viktorija Augutiene $\dot{e}^{1}$ \\ Lietuvos kūno kultūros akademija ${ }^{1}$, Kauno medicinos universitetas ${ }^{2}$, \\ Kauno technologijos universitetas ${ }^{3}$, Kaunas, Lietuva
}

\begin{abstract}
Renata Žumbakytė. Kauno medicinos universiteto Kardiologijos instituto medicinos mokslų doktorantè, sporto medicinos gydytoja, Lietuvos kūno kultūros akademijos Eksperimentinès plètros centro jaunesnioji mokslo darbuotoja, Kauno medicinos universiteto Kineziologijos ir sporto medicinos katedros lektorè. Mokslinių tyrimų kryptis — sportuojančiujų funkcinès būklès ịvertinimas funkciniais mėginiais.
\end{abstract}

\section{SANTRAUKA}

Tyrimo tikslas - ištirti krepšininku, futbolininku ir nesportuojančiu asmenu (vyru ir moteru) organizmo atsigavimo reakcijos po dozuoto fizinio krūvio kaita bei fiziologiniu rodikliu stabiluma.

Buvo tiriami 267 asmenys: trys vyru (krepšininku (KV), futbolininku (FV) ir nesportuojančiuju (NV)) ir dvi moteru (krepšininkiu (KM) ir nesportuojančiuju (NM)) grupés.

Norèdami išsamiau išanalizuoti sportininku atsigavimo po dozuoto fizinio krūvio kaita, taikème integralios organizmo reakcijos i fizini krūvi modeli, kuris apima reguliacinès (centrinès nervu sistemos, autonominio ir humoralinio valdymo), aprüpinančiosios (kvèpavimo, širdies ir kraujagysliu sistemu) ir vykdančiosios (fizinio krūvio metu veikliu raumenu grupés) sistemu tarpusavio sasajos poreiški krūvio metu. Naudota KMU Kardiologijos institute sukurta automatizuota EKG analizès sistema „Kaunas-Krūvis”, kuri sinchroniškai registruoja ir analizuoja asmens išugdoma raumenu galinguma, arterini kraujo spaudima ir EKG. Atliktas kompiuterizuotas veloergometrinis kiekvieno tiriamojo fizinio krūvio méginys, naudojant trumpalaiki (provokacini) tyrimo protokola. Sveikos nesportuojančios moterys krūvi pradejo atlikti nuo $50 \mathrm{~W}$ galingumo ir kas minute didino ji po $25 \mathrm{~W}$ iki submaksimalaus $(50+n \times 25 \mathrm{~W})$. Kiti tiriamieji krūvi pradejo atlikti nuo $50 \mathrm{~W}$ galingumo ir kas minutęj didino po $50 \mathrm{~W}$ iki submaksimalaus $(50+n \times 50 \mathrm{~W})$. Vertinti šie fiziologiniu rodikliu grǐžimo ì pradinị lygị pusperiodžiai: širdies susitraukimu dažnio (T (HR)), intervalo $J T$, t. y. (T (JT)), sistolinio arterinio kraujo spaudimo (T (S)), santykinés repoliarizacijos JT / RR, t. y. T (JT / RR), ir santykinès pulsinés amplitudès $T((S-D) / S)$. S ir HR dydžiai labiau sietini su reguliacija, o $(S-D) / S$ ir JT - su atskiru organu funkcija, ir nusako periferijos atsakq. Naudodami Liapunovo eksponentę (L (X)), ivertinome minètu fiziologiniu rodikliu stabiluma.

Alike tyrima padarème tokias išvadas: 1) atsigavimo rodikliai patikimai skiriasi atsigavimo greičiu ir stabilumu; 2) futbolininku, krepšininku, nesportuojančiu, vyru ir moteru atskirufiziologiniu procesu atsigavimo greičiai, stabilumas bei juos lemiantys veiksniai skiriasi.

Raktažodžiai: sportininko širdis, elektrokardiogramos pokyčiai, krūvis, atsigavimas.

\section{IVADAS}

$\mathrm{O}$ rganizmo pokyčiai, atsirandantys krūvio metu, - sudėtingų, tarpusavyje susijusiu procesų virtinè. Šiu pokyčių optimali tėkmè, leidžianti adekvačiai adaptuotis prie atliekamo krūvio dydžio ir specifikos, nesukeliant žalingų reiškinių pačiam sportininkui, ir yra sporto medicinos gydytoju bei sporto mokslininku pagrindinis rūpestis, kuris taip pat svarbus funkcinès diagnostikos srityje (Froelicher, Myers, 2000).
Sveikata, gera žmogaus fizinè ir funkcinè būklè neatsiejama nuo adekvataus fizinio aktyvumo. Todèl būtina vertinti sportininko sveikatos būklę, jo adaptaciją prie fizinio krūvio. Norint įvertinti sportininko funkcinę būklę, būtina parinkti adekvačius fizinius krūvius ir pritaikyti biologiškai aktyvias medžiagas. Sporto medicinoje, tiriant sportininkus, dažniausiai nagrinejjami fiziologiniai ramybės rodikliai atliekant maksimaluji krūvị ir 


\begin{tabular}{|c|c|c|c|c|c|c|c|}
\hline \multirow[t]{6}{*}{$\begin{array}{l}\text { Lentelé. Nagrinėtų grupių } \\
\text { charakteristikos (duome- } \\
\text { nys pateikti } M \pm \text { SD) }\end{array}$} & Grupè & $\begin{array}{l}\text { Imties } \\
\text { dydis }\end{array}$ & $\begin{array}{l}\text { Amžius, } \\
\mathrm{m} .\end{array}$ & $\begin{array}{l}\text { Uggis, } \\
\mathrm{cm}\end{array}$ & $\begin{array}{l}\text { Svoris, } \\
\mathrm{kg}\end{array}$ & $\begin{array}{c}\text { Santykinis } \\
\text { atlikto } \\
\text { darbo } \\
\text { galingumas, } \\
\mathrm{W} / \mathrm{kg}\end{array}$ & $\begin{array}{l}\text { Sportinis } \\
\text { stažas, } m \text {. }\end{array}$ \\
\hline & $\begin{array}{l}\text { Vyrai krepšininkai } \\
(\mathrm{KV})\end{array}$ & 108 & $\begin{array}{l}20,43 \pm \\
4,99\end{array}$ & $\begin{array}{l}194,08 \pm \\
9,08\end{array}$ & $\begin{array}{l}85,07 \pm \\
13,89\end{array}$ & $\begin{array}{l}2,738 \pm \\
0,998\end{array}$ & $\begin{array}{l}10,04 \pm \\
3,77\end{array}$ \\
\hline & $\begin{array}{l}\text { Vyrai futbolininkai } \\
\text { (FV) }\end{array}$ & 55 & $\begin{array}{l}22,36 \pm \\
4,36\end{array}$ & $\begin{array}{l}183,62 \pm \\
6,22\end{array}$ & $\begin{array}{l}78,34 \pm \\
7,77\end{array}$ & $\begin{array}{l}2,97 \pm \\
0,42\end{array}$ & $\begin{array}{l}13,69 \pm \\
4,81\end{array}$ \\
\hline & $\begin{array}{l}\text { Nesportuojantys } \\
\text { vyrai (NV) }\end{array}$ & 30 & $\begin{array}{l}25,83 \pm \\
7,38\end{array}$ & $\begin{array}{l}178,9 \pm \\
6,51\end{array}$ & $\begin{array}{l}78,37 \pm \\
14,99\end{array}$ & $\begin{array}{l}2,161 \pm \\
0,681\end{array}$ & 0 \\
\hline & $\begin{array}{l}\text { Moterys } \\
\text { krepšininkès (KM) }\end{array}$ & 40 & $\begin{array}{l}22,4 \pm \\
5,89\end{array}$ & $\begin{array}{l}180,6 \pm \\
6,57\end{array}$ & $\begin{array}{l}72,4 \pm \\
8,39\end{array}$ & $\begin{array}{l}2,817 \pm \\
0,464\end{array}$ & $\begin{array}{l}12,23 \pm \\
6,36\end{array}$ \\
\hline & $\begin{array}{l}\text { Nesportuojančios } \\
\text { moterys (NM) }\end{array}$ & 34 & $\begin{array}{l}28,59 \pm \\
6,58\end{array}$ & $\begin{array}{l}166,85 \pm \\
6,43\end{array}$ & $\begin{array}{l}66,88 \pm \\
11,93\end{array}$ & $\begin{array}{l}1,765 \pm \\
0,389\end{array}$ & 0 \\
\hline
\end{tabular}

atsigavimo metu. Daugybė fiziologinių reakcijų, svarbių vertinant sportininko būseną, atsiskleidžia atsigavimo metu po dozuoto fizinio krūvio. Nors šis etapas svarbus vertinant sportininko funkcinę būklę, tačiau, kaip formalūs rodikliai veikia atsigavimo kaita, pasaulinèje literatūroje pateikta mažai. Literatūroje organizmo funkcinès būklès atsigavimo kaita dažniausiai vertinama pagal ịprastus funkcinius rodiklius (širdies susitraukimų dažnį, arterini kraujo spaudimą), kurie parodo reguliuojamosios sistemos ypatumus. Anksčiau pateiktuose darbuose nagrinejjome atsigavimo laikotarpio ypatumus tarp skirtingo treniruotumo moteru (Zumbakyte et al., 2003; Kajènienè ir kt., 2002). Yra nagrinèti nesportuojančių vyrų ir moterų bei sveikatingumo grupes lankančių vyrų ir moterų (Šilanskienè, 2003), taip pat moteru, lankančiu dvejopo pobūdžio fizinio krūvio (lokalieji pratimai, skirti atskirų raumenu grupių funkciniam pajègumui didinti arba aerobiniai acikliniai pratimai) sveikatingumo pratybas, organizmo atsigavimo laikotarpio rodikliai (Vitartaite ir kt., 2004).

Šiuo tyrimu noredami ịvertinti vyrų krepšinin$\mathrm{ku}$, futbolininkų ir moterų krepšininkių organizmo atsigavimo laikotarpio ypatumus, naudojome EKG analizès sistemą „Kaunas-Krūvis“. Lygiagrečiai su EKG registruodami kūno judejjimo charakteristikas (išugdomą darbo galingumą), arterinị kraujo spaudimą (AKS) ar kitus hemodinaminius procesus, galime atskleisti ir vertinti esminių žmogaus organizmo sistemų sinergetinius veiksnius, ypač praplečiančius funkcinès diagnostikos galimybes. Šių savybių idiegimas i praktiką leidžia kurti sistemas, tinkamas naudoti tiek klinikinejje praktikoje, tiek sporto medicinoje, vertinant sportuojančio asmens funkcines galimybes, kompensacinius mechanizmus ir tarpsisteminių ryšių ypatumus.
Tai ypač aktualu ir naudinga sporto medicinos praktikai ir netgi epidemiologiniu studijų metu. Tai svarbu ir sporto mokslininkams, treneriams, individualizuojant sportuojančio asmens fizini krūvị ir siekiant geriausio sportinio rezultato, nesukeliant žalos sportininko sveikatai.

Tyrimo tikslas - ištirti krepšininkų, futbolininkų ir nesportuojančių asmenų (vyrų ir moterų) organizmo atsigavimo reakcijos po dozuoto fizinio krūvio kaitą ir fiziologinių rodiklių stabilumą.

\section{METODIKA}

Buvo tiriami 267 asmenys, savo noru atvykę konsultuotis pas sporto medicinos gydytoją ir norintys sužinoti savo organizmo funkcinę būklę bei fizini pajègumą. Jie buvo suskirstyti į skirtingas grupes pagal lytị ir sporto šaką. Tirtos trys vyru (krepšininku (KV), futbolininkų (FV) ir nesportuojančiuju (NV)) ir dvi moteru (krepšininkiu $(\mathrm{KM})$ ir nesportuojančiuju (NM)) grupès. Nagrinètú grupių charakteristikos pateiktos lenteleje.

Naudota KMU Kardiologijos institute sukurta automatizuota EKG analizès sistema „KaunasKrūvis“, kuri sinchroniškai registruoja ir analizuoja asmens išugdomą raumenų galingumą, arterini kraujo spaudimą ir EKG (Vainoras, 1996).

Atliktas kiekvieno tiriamojo kompiuterizuotas veloergometrinis fizinio krūvio mėginys, naudojant trumpalaiki (provokacini) tyrimo protokolą (Vainoras ir Jaruševičius, 1996). Sveikos nesportuojančios moterys krūvi pradèjo atlikti nuo $50 \mathrm{~W}$ galingumo ir kas minutę ji didino po $25 \mathrm{~W}$ iki submaksimalaus $(50+\mathrm{n} \times 25 \mathrm{~W})$ (submaksimalus galimas, bet nebūtinas galingumas - iprastai galingumas ribojamas klinikinių požymių poreiškiu). Kiti tiriamieji krūvị pradejo atlikti nuo $50 \mathrm{~W}$ galingumo ir 
kas minute ji didino po $50 \mathrm{~W}$ iki submaksimalaus $(50+\mathrm{n} \times 50 \mathrm{~W})$. Veloergometrinio tyrimo metu, registruojant kelių tarpusavyje susijusių pagrindinių organizmo sistemų, t. y. vykdančiosios (periferija) $(\mathrm{P})$, aprūpinančiosios $(\mathrm{H})$ ir reguliacinès (R) rodiklius, buvo vertinamos tiek pavienès, tiek integruotos minètų sistemų funkcijos. Vertinti fiziologinių rodiklių atsigavimo pusperiodžiai, t. y. dydžio kitimas atsigavimo metu iki pusès buvusios reikšmès, laikas skaičiuojamas sekundėmis. Nagrinèti širdies susitraukimų dažnio (T (HR)), intervalo JT (elektrokardiogramoje nuo jungties taško J iki T bangos pabaigos), t. y. (T (JT)), sistolinio arterinio kraujo spaudimo (T (S)) ir išvestinių dydžių — santykinès repoliarizacijos JT / RR, t. y. T (JT / RR), bei santykinès pulsinès amplitudès $\mathrm{T}((\mathrm{S}-\mathrm{D}) / \mathrm{S})$ (čia D yra diastolinis kraujo spaudimas) atsigavimo pusperiodžiai. S ir HR dydžiai labiau sietini su reguliacija, o (S - D) / S ir JT — su atskirų organų funkcija, ir nusako periferijos atsaka. Liapunovo eksponente $(\mathrm{L}(\mathrm{X}))$ įvertinome minètų fiziologiniu rodikliu stabilumą. Priimtina procesu normalizavimosi eigą vertinti kaip stabilią, kai L (X) - mažesnè už nulị, o nestabilią, kai L (X) - didesnè už nuli. Liapunovo eksponentė (L (X)) apskaičiuota pagal formulę:

$$
\mathrm{L}(\mathrm{X})=1 / \mathrm{N} \sum_{\mathrm{i}=1}^{\mathrm{N}} \ln \left(\mathrm{X}_{\mathrm{i}+1} / \mathrm{X}_{\mathrm{i}}\right) \quad(\text { kai N }=\overline{1,5})
$$

čia X - rodiklis.

Tyrimo duomenų analizė atlikta naudojant SPSS 13.0 programą. Buvo apskaičiuojamas aritmetinis vidurkis, standartinis nuokrypis ir nepriklausomų imčių vidurkio skirtumų reikšmingumas - pagal Stjudento $t$ kriterijų. Vidurkiu skirtumas laikytas patikimu, jei paklaidos tikimybe mažesnè nei 0,05 .

\section{REZULTATAI}

Fiziologinių rodikliu grižimo i pradinị lygi pusperiodžių ir fiziologinių procesų stabilumo kaita pateikta 1 ir 2 paveiksle.

Nagrinėdami gautus duomenis pastebejome, kad skirtingi fiziologiniai rodikliai labai skiriasi grižimo i pradini lygi greičiu (1 pav.). Matyti, kad visose grupèse greičiausiai i pradini lygi sugrįzo santykinès repoliarizacijos (JT / RR) atsigavimo pusperiodžių rodikliai (T (JT / RR)), paskui — širdies susitraukimų dažnio (T (HR)) ir sistolinio kraujo spaudimo (T (S)), intervalo JT (T (JT)) ir santykinès pulsinès amplitudès $(\mathrm{T}((\mathrm{S}-\mathrm{D}) / \mathrm{S}))$.

Lyginome fiziologinių rodikliu grįzimo i pradini lygi pusperiodžių rodiklius tarp atskiru grupių. Pastebèta, kad krepšininkių moterų santykinès repoliarizacijos (T (JT / RR)) ir sistolinio arterinio kraujo spaudimo (T (S)) pusperiodžių rodikliai grižta i pradini lygi per ilgesnị laiką nei nesportuojančių moterų $(\mathrm{p}<0,05)$. Lyginant futbolininkų ir nesportuojančių vyru grupes, nustatytas patikimai trumpesnis $(\mathrm{p}<0,05)$ intervalo JT rodikliu sugrį̌imo i pradini lygi pusperiodis (T (JT)) nesportuojančių vyru grupejje. Lyginant krepšininku ir nesportuojančiu vyru grupes, intervalo JT pusperiodis (T (JT)) taip pat yra trumpesnis nesportuojančių vyrų grupejje, tačiau patikimo rodiklių skirtumo neaptikta. Idomus skirtumas nustatytas lyginant vyrų futbolininku ir krepšininkų grupių rodiklius tarpusavyje. Pastebèti patikimai trumpesni pusperiodžiai T (JT), T (HR), T (JT / RR) ir $\mathrm{T}((\mathrm{S}-\mathrm{D}) / \mathrm{S})$ vyrų krepšininkų grupejje nei vyrų futbolininku. Nors patikimo skirtumo tarp atlikto darbo galingumo šiose grupèse nèra.

Palyginome ir fiziologiniu rodikliu grižimo i pradini lygi pusperiodžius tarp lyčių. Palyginus

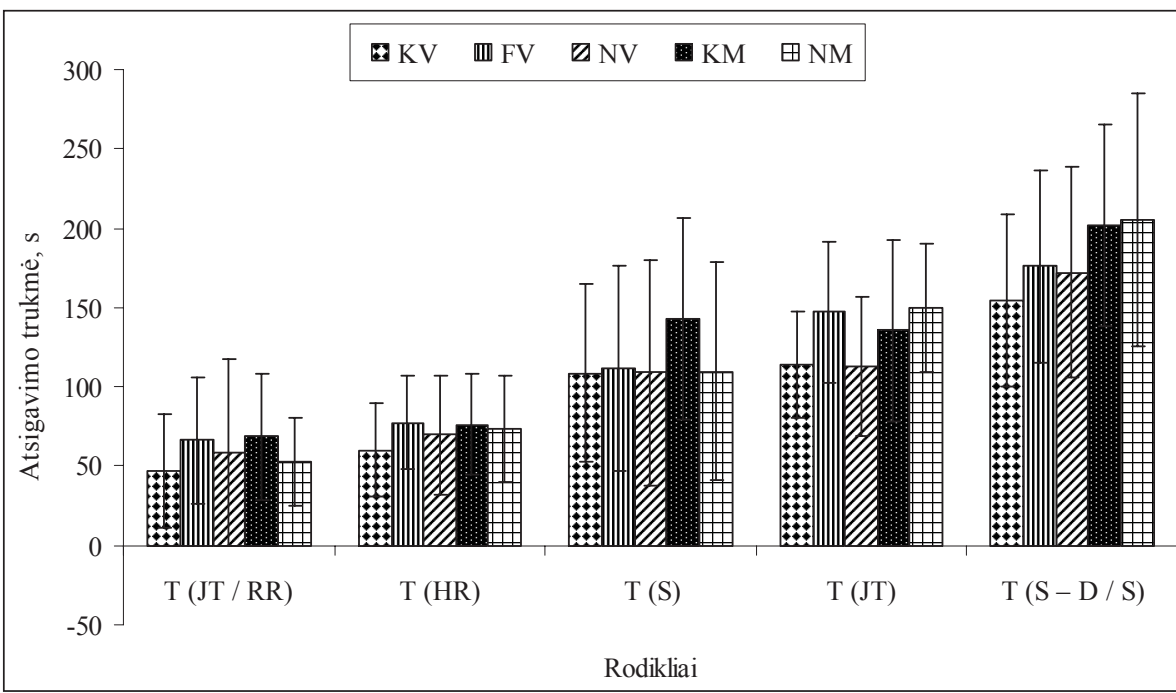

1 pav. Tirtų sportininkų ir nesportuojančiu grupių rodiklių grị̌žmo ị pradinị lygị pusperiodžių trukmè 
2 pav. Liapunovo eksponenčių kitimas nagrinètose grupèse

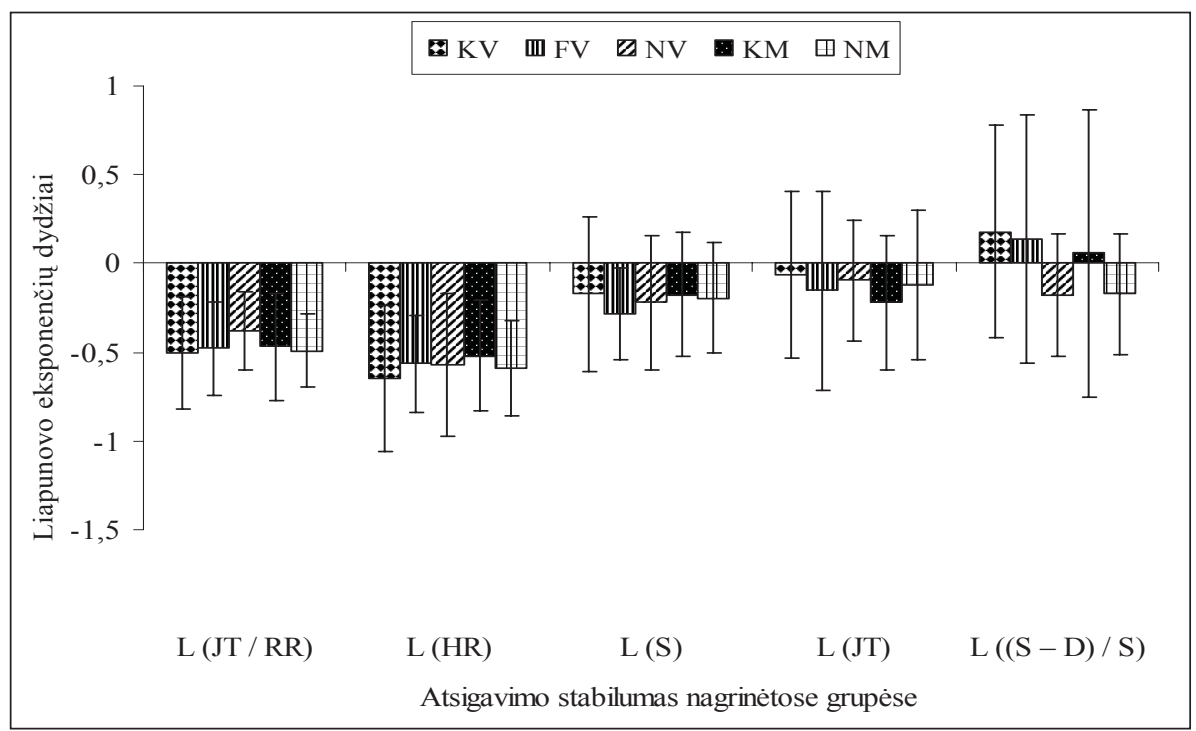

krepšininkų vyrų ir moterų rodiklius paaiškejjo, kad vyrų pusperiodžiai T (HR), T (S), T (JT / RR) ir $(\mathrm{T}(\mathrm{S}-\mathrm{D}) / \mathrm{S})$ patikimai $(\mathrm{p}<0,05)$ trumpesni nei moterų. Palyginus nesportuojančių vyrų ir moterų fiziologinių rodikliu grižimo i pradinị lygi laikotarpius, aptiktas patikimai trumpesnis vyru $\mathrm{T}(\mathrm{JT})$ nei moteru $(\mathrm{p}<0,05)$.

Fiziologinio proceso stabilumą nusakème Liapunovo eksponente (L (X)). Gautus duomenis pateikème 2 paveiksle. Nagrinejjant duomenis matyti, kad atskirų fiziologiniu procesų stabilumas taip pat skyrèsi. Stabiliausiai grižta i pradinį lygi širdies susitraukimų dažnio (HR) ir santykinès repoliarizacijos (JT / RR) rodikliai, o santykinès pulsinès amplitudès ( $(\mathrm{S}-\mathrm{D}) / \mathrm{S})$ - nestabiliausiai. Lyginant nesportuojančiujų vyrų grupę su futbolininkais ir krepšininkais, L ((S - D) / S) patikimai skyrèsi $(\mathrm{p}<0,05)$. Nesportuojančiujų grupèje pastebèta, kad santykinès pulsinès amplitudès rodikliai grižžta i pradinị lygị stabiliai ( $(\mathrm{S}-\mathrm{D})$ / S - mažesnè už nuli), o krepšininkų ir futbolininkų - nestabiliai (L (S - D) / S - didesné už nuli). L ((S - D) / S) rodiklių skirtumas tarp krepšininkų ir nesportuojančiuju, tarp futbolininkų ir nesportuojančiuju yra patikimas $(p<0,05)$. Lygindami nesportuojančiu vyrų ir krepšininkų fiziologinių procesų stabilumą pastebejome, kad patikimai stabiliau grįžta i pradini lygi krepšininku santykinès repoliarizacijos (L (JT/RR)) rodikliai $(\mathrm{p}<0,05)$. Patikimo šių rodiklių skirtumo neaptikome palyginę nesportuojančiujų ir futbolininku vyru grupes. Lyginant krepšininku ir futbolininku vyru fiziologiniu procesu stabilumą, aptiktos patikimai stabilesnès futbolininkų sistolinio arterinio kraujo spaudimo (S) atsigavimo reakcijos. Moteru (krepšininkiu ir nesportuojančiuju) grupèse fiziologinių procesų sta- bilumas patikimai nesiskyrè. Lyginome krepšininkų ir nesportuojančiujų asmenų rodiklių skirtumą tarp lyčių. Krepšininkių ir krepšininkų fiziologiniu procesų stabilumas patikimai nesiskyrè, o nesportuojančiu moterų santykinès repoliarizacijos grižimo i pradini lygi rodikliai (JT / RR) buvo patikimai stabilesni nei nesportuojančių vyrų $(\mathrm{p}<0,05)$.

\section{REZULTATU APTARIMAS}

Vertindami fiziologinių rodiklių grižimo i pradini lygi pusperiodžius pastebejome, kad visose tirtose grupèse greičiausiai grižta i pradini lygị reguliacinès ir aprūpinamosios sistemų ryšys (būtent JT / RR). Tai, matyt, leidžia mobilizuoti išnaudotus rezervus reguliacinès (ją apibūdina HR ir S), aprūpinamosios (ją apibūdina JT intervalas) sistemų ir periferijos rodikliu $((\mathrm{S}-\mathrm{D}) / \mathrm{S})$ grižimą i pradini lygi. Šis eiliškumas turi fiziologinę prasmę. Didžiausią darbą atliekantiems raumenims atsigauti reikia daugiausia laiko. Panaši šių fiziologiniu rodikliu grižimo i pradini lygi pusperiodžių seka buvo aprašyta ankstesniuose darbuose, nagrinėjančiuose nesportuojančių (Šilankiené, 2003) moterų, lankančių dvejopo pobūdžio fizinio krūvio sveikatingumo pratybas (Vitartaitè ir kt., 2004), krepšininkių ir nesportuojančių moterų (Žumbakytè et al., 2003) šiuos rodiklius.

Tyrimo metu gauta, kad nesportuojančiu moterų santykinès repoliarizacijos (T (JT / RR)) ir sisgrįžimo i pradini lygi pusperiodžiai yra patikimai trumpesni nei krepšininkių $(\mathrm{p}<0,05)$. Tai gali būti susiję su tuo, kad reguliacinių sistemų apkrova yra kur kas didesnè, išugdžius didesni fizinio darbo galingumą (krepšininkių santykinis atlikto dartolinio arterinio kraujo spaudimo $(\mathrm{T}(\mathrm{S}))$ rodiklių 
bo galingumas patikimai didesnis $(\mathrm{p}<0,05)$ nei nesportuojančiu moteru). Tačiau tokiu patikimu santykines repoliarizacijos ir sistolinio arterinio kraujo spaudimo rodikliu grižimo i pradini lygi pusperiodžiu tarp nesportuojančiuju ir krepšininkų vyrų bei tarp nesportuojančiujų ir futbolą žaidžiančių vyrų nenustatėme, nors santykinis krepšininkų ir futbolininku atlikto darbo galingumas buvo patikimai didesnis.

Vertinant aprūpinančiosios sistemos atsigavimą po krūvio gauta, kad nesportuojančių vyru JT intervalo trukmès rodikliai patikimai greičiau grižta i pradini lygi nei futbolininkų (patikimai skyrèsi santykinis atlikto darbo galingumas) ir greičiau nei krepšininkų (patikimai skyrèsi santykinis atlikto darbo galingumas). Nesportuojančiu vyrų JT intervalo rodikliai patikimai greičiau grižta i pradini lygi nei nesportuojančių moteru, tačiau patikimai skiriasi santykinis atlikto darbo galingumas. Be to, krepšininkų JT intervalo rodikliai patikimai greičiau grižta i pradini lygi nei futbolininku, nors patikimo santykinio atlikto darbo galingumo skirtumo tarp šių grupių sportininkų neaptikta. Vertinant krepšininkų ir futbolininkų vyrų grupių atsigavimą po krūvio, gauti ir kiti patikimai trumpesni fiziologinių rodiklių grįzimo i pradini lygi pusperiodžiai: reguliacinę sistemą apibūdinantis T (HR), reguliacinès ir aprūpinančiosios sistemos ryši $\mathrm{T}(\mathrm{JT} / \mathrm{RR})$ ir periferiją — santykinè pulsinè amplitudè - T ( $(S-D) / S)$. Tačiau futbolininkai vyrai patikimai daugiau metų sportavo nei krepšininkai vyrai $(p<0,05)$. Galbūt skiriasi krepšininku ir futbolininkų vyrų suminis fizinio krūvio poveikis organizmui, treniruočių kontrole ar maisto papildų vartojimas? Galima būtų manyti, kad JT intervalo rodikliu grižimo ị pradini lygi pusperiodis (kartu ir širdies metaboliniai procesai) ilgèja priklausomai nuo sportavimo laiko, suminio fizinio krūvio poveikio organizmui, treniruočių pobūdžio, pertreniravimo ar maisto papildų vartojimo sportuojant. Tai turètų būti tolimesnių studijų objektas.

Palyginus krepšininkų vyrų ir moteru atsigavimo po dozuoto fizinio krūvio laikotarpi matyti, kad patikimai greičiau grižta i pradini lygi krepšininkų vyrų nei krepšininkių moterų reguliacinès sistemos (HR ir S), reguliacinès ir aprūpinamosios sistemos ryšio (JT / RR) bei periferiją apibūdinan- čios santykinès pulsinès amplitudès $((S-D) / S)$ rodikliai. Nors patikimo skirtumo tarp atlikto santykinio darbo galingumo vyrų krepšininkų ir moterų krepšininkių grupių nenustatyta.

Paskutiniais metais atlikta daug studijuc, nagrinejjančių kompleksinį fizinio krūvio poveiki organizmui (Biggiero, 2001). Todèl norèdami išsamiau išanalizuoti sportininkų atsigavimo po dozuoto fizinio krūvio kaitą taikeme integralios organizmo reakcijos ị fizinị krūvị modeli (Vainoras, 1996; Vainoras et al., 1999; Poderys, 2004), kuris apima reguliacinès (centrinès nervų sistemos, autonominio ir humoralinio valdymo), aprūpinančiosios (kvèpavimo, širdies ir kraujagyslių) ir vykdančiosios (fizinio krūvio metu veiklių raumenų grupès) sistemų tarpusavio sąsają krūvio metu.

Liapunovo eksponentė dažnai naudojama kaip proceso kitimo stabilumo rodiklis (Suetani et al., 2004). Vertindami fiziologiniu procesu stabilumą pastebejjome, kad visų sportuojančiuju (krepšininkų vyru ir moteru, vyrų futbolininkų) grupèse po dozuoto fizinio krūvio yra nestabilūs santykinès pulsinès amplitudès $((\mathrm{S}-\mathrm{D})$ / S) grį̌imo ì pradini lygi rodikliai, o nesportuojančiuju — stabilūs. Matyt, tai yra susiję su kasdien atliekamu didesniu fiziniu krūviu ir periferijos perkrova. Tyrimo metu nustatyta, kad patikimai stabilesni krepšininkų reguliacinès ir aprūpinančiosios sistemos ryšio (JT / RR) grižimo i pradini lygi rodikliai nei nesportuojančiu vyru, o nesportuojančių moteru - nei nesportuojančių vyrų. Reguliacinės ir aprūpinančiosios sistemos ryšys (JT / RR) bei reguliacinę sistemą apibūdinančio širdies susitraukimų dažnio (HR) rodikliai ne tik greičiausiai grižta i pradini lygi, bet ir yra stabiliausi, ir tai, matyt, greičiausiai užtikrina visą atsigavimo procesą ir yra svarbūs vertinant funkcinę sportininko būklę bei planuojant atsigavimo laikotarpi.

\section{IŠVADOS}

1. Atsigavimo rodikliai patikimai skirtingu greičiu grižta i pradinị lygị ir yra nevienodo stabilumo.

2. Futbolininkų, krepšininkų, nesportuojančiujjų, vyrų ir moterų atskirų fiziologinių procesų atsigavimo greičiai, stabilumas bei juos lemiantys veiksniai skiriasi.

\section{LITERATŪRA}

Biggiero, L. (2001). Sourus of complexity in human systems. J. Nonlinear Dynamics. Psychology and Life Sciences, $5(1), 379$.

Froelicher, V., Myers, J. N. (2000). Exercise and the heart $\left(4^{\text {th }}\right.$ ed.). Philadelphia, London, Toronto, Sydney: W. B. Saunders Company. P. 456.

Kajènienè, A., Vainoras, A., Žumbakytè, R. ir kt. (2002). Dozuoto fizinio krūvio mèginio atsigavomo laikotarpio 
fiziologiniu parametrų vertinimas. Biomedicinine inžinerija: tarptautinès konferencijos pranešimu medžiaga (pp. 147-150). Kaunas: Technologija.

Poderys, J. (2004). Kineziologijos pagrindai: mokomoji knyga. Kaunas.

Suetani, H., Horita, T., Mizutani, S. (2004). Noise-induced enhancement of fluctuation and spurious synchronization in uncoupled type-I intermittent chaotic systems. Phys Rev E Stat Nonlin Soft Matter Phys, 69 (1 Pt 2); 016219.

Šilanskienè, A. (2003). Žmogaus organizmo funkcinès būklès kitimo ilgalaikiu treniruočiu metu vertinimas: daktaro disertacijos santrauka. Kaunas: KMU.

Vainoras, A., Gargasas, L., Jaruševičius, G. et al. (1999). The bicycle ergometry and possibility of complex evaluation. Lithuanian Journal of Cardiology, 6 (4), 760-763.
Vainoras, A. (1996). Investigation of the Heart Repolarization Process During Rest and Bicycle Ergometry (100-lead and standard 12-lead ECG data): Synopsis of D. Sc. Habil. Thesis. Kaunas.

Vainoras, A., Jaruševičius, G. (1996). Veloergometrija: mokymo metodine priemone. Kaunas. P. 2-3.

Vitartaite, A., Vainoras, A., Sendžikaité, E. (2004). Moteru atsigavimo po fizinio krūvio fiziologiniu parametru ypatumai. Biomedicininè inžinerija: tarptautinés konferencijos pranešimu medžiaga. (pp. 62-65). Kaunas: Technologija.

Zumbakytė, R., Kajenienè, A., Vainoras, A. (2003). Computerized evaluation of recovery phase in women after bicycle test. International Journal of Computer Science in Sport, Vol. 2, 196-198. Prieiga per interneta: URL:http://www.iacss.org.

\title{
RECOVERY FEATURES OF BASKETBALLERS, SOCCER PLAYERS AND PERSONS WITHOUT SPORT ACTIVITY AFTER SUBMAXIMAL PHYSICAL LOAD TEST
}

\author{
Renata Žumbakyte் $\dot{e}^{1,2}$, Alfonsas Vainoras ${ }^{2}$, Alma Kajèniene் ${ }^{2}$, \\ Kristina Berškiene் $\dot{2}^{2,3}$, Viktorija Augutienè ${ }^{1}$ \\ Lithuanian Academy of Physical Education ${ }^{l}$, Kaunas Medical University ${ }^{2}$, \\ Kaunas University of Technology, Kaunas, Lithuania
}

\begin{abstract}
The aim of the study was investigation of recovery process, its speed and stability for basketballers, soccer players and persons without sport activity.

2 groups of women were investigated: KM group - 40 basketballers, NM group - 34 persons without sport activity and 3 groups of men: KV group - 108 basketballers, FV group - 55 soccer players, NV group - 30 persons without sport activity.

There are a lot of situations when we need to evaluate features of organism reactions to load. We can investigate human organism during and after load by computerized bicycle ergometry analysis system "Kaunas-Load". According to physiologic changes in human organism during load, the main systems responsible for organism functionality could be - working muscles (P), responsible for energy supply-cardiovascular system (H), for oxygen supply - lungs (L) and coordinating all that systems function together - regulatory system (R) (in which as one could be accounted central nervous system, periphery nervous system, humoral regulation etc.). Two systems responsible for supply — cardiovascular and respiratory — could be reduced to one supplying system $(\mathrm{H})$.

Computerized bicycle ergometry analysis system "Kaunas_Load" was used for all investigated persons. The protocol for investigation was provocative protocol with decreased to one-minute time interval for one step. Load for every woman without sport activity was begun from $50 \mathrm{~W}$ and every one-minute was added $25 \mathrm{~W}$ to sub maximal developed power. Load for every sportsman and man without sport activity was begun from $50 \mathrm{~W}$ and every oneminute was added $50 \mathrm{~W}$ to sub maximal developed power. At every step of strain were recorded: load, arterial blood pressure and 12 ECG (electrocardiogram) leads synchronously. Half periods of recovery were analyzed: systolic arterial blood pressure $-\mathrm{T}(\mathrm{S})$, heart rate $-\mathrm{T}(\mathrm{HR})$, JT interval $-\mathrm{T}(\mathrm{JT})$, ratio of interval JT and RR - T (JT / RR), ratio of pulse amplitude and systolic arterial blood pressure - T ((S - D) / S). Lyapunov exponent was calculated for all earlier described parameters to evaluate their stability during recovery process.

We draw inferences after this research work: a) parameters have different recovery half periods and stability; b) there was different dynamic of recovery evaluated by half periods as well as stability of recovery process evaluated by Lyapunov exponents in the investigated groups.
\end{abstract}

Keywords: athlete's heart, ECG (electrocardiogram) changes, load, recovery.

Renata Žumbakytè

Lietuvos kūno kultūros akademija

Gauta 2006 m. gegužès 25 d.

(Lithuanian Academy of Physical Education)

Received on May 25, 2006

Perkūno al. 3, LT-44221 Kaunas

Priimta 2006 m. rugsejjo 12 d.

Accepted on September 12, 2006

Lietuva (Lithuania)

Tel +37037302649

E-mail r.zumbakyte@1kka.1t 